\title{
ANALISIS KINERJA PERBANKAN SYARIAH DI INDONESIA DAN MALAYSIA DENGAN PENDEKATAN MAQASHID INDEKS
}

\author{
Muhammad Al Ghifari ${ }^{1}$, dan Luqman Hakim Handoko ${ }^{2}$ dan Endang \\ Ahmad Yani ${ }^{3}$
}

1 Program Studi Perbankan Syariah, Sekolah Tinggi Ekonomi Islam SEBI, Depok, Jawa Barat. Email: ghifarialhafizd@gmail.com

2 Program Studi Perbankan Syariah, Sekolah Tinggi Ekonomi Islam SEBI, Depok, Jawa Barat. Email: hakimbao1@yahoo.com

${ }^{3}$ Program Studi Perbankan Syariah, Sekolah Tinggi Ekonomi Islam SEBI, Depok, Jawa Barat. Email: ahyani2009@gmail.com

\begin{abstract}
ABSTRAK: Penilaian kinerja perbankan syariah biasanya menggunakan alat ukur konvensional. Padahal untuk menilai kinerja perbankan syariah tidak dapat disamakan dengan perbankan konvensional, karena keduanya memiliki tujuan dan pandangan yang berbeda. Penelitian ini bertujuan untuk mengetahui kinerja perbankan syariah dengan pendekatan maqashid indeks. Objek penelitian terdiri dari empat bank syariah di Indonesia (Bank Syariah Mandiri, Bank Muamalat Indonesia, Bank Rakyat Indonesia Syariah dan Bank Negara Indonesia Syariah) dan empat bank syariah Malaysia (Bank Islam Malaysia Berhad, CIMB Islamic Bank, Maybank Islamic Berhad dan RHB Islamic Bank) selama tahun 2011-2014. Kemudian, bank syariah diukur dan diranking kinerjanya berdasarkan tiga langkah: 1) rasio kinerja 2) indikator kinerja dan 3) maqashid indeks secara keseluruhan. Berdasarkan hasil penelitian, dapat disimpulkan bahwa Bank Muamalat Indonesia memiliki kinerja tertinggi di dengan nilai 15.12\%. Selanjutnya, kinerja terendah terjadi di CIMB Islamic Bank dengan 7.02\%.
\end{abstract}

Kata Kunci: Penilaian Kinerja, Perbankan Syariah, Indonesia, Malaysia and Maqashid Indeks

\begin{abstract}
The measurement of Islamic banking usually uses a conventional measurement. But to evaluate performance of Islamic banking can not be equated to conventional banks, because they have different purpose and views. Therefore aims to understand the performance of Islamic banks based on the maqashid index approach. Objects research consisting of four Islamic banks in Indonesia (Bank Syariah Mandiri, Bank Muamalat indonesia, Bank Rakyat Indonesia Syariah and Bank Negara Indonesia Syariah) and four Islamic banks in Malaysia (Bank Islam Malaysia Berhad, CIMB Islamic Bank, Maybank Islamic Berhad and RHB Islamic Bank) for years 2011-2014. Then, Islamic banks measured and rank its performance based on three steps: 1) the ratio performance 2) performance indicators and 3) the overall maqashid index. The research showed, that Bank Muamalat Indonesia has the highest performance is $15.12 \%$. Next, the lowest performance is $7.02 \%$ by CIMB Islamic Bank.
\end{abstract}

Keywords: Performance Measurement, Islamic Banking, Maqashid Index and . 
48 | AL-Ghifari, Handoko \& Yani: Analisis Kinerja Perbankan Syariah Di Indonesia Dan Malaysia.........

\section{PENDAHULUAN}

Bank syariah tumbuh di seluruh dunia, bukan hanya di negara-negara dengan mayoritas penduduk muslim seperti Indonesia, Malaysia, dan negara-negara timur tengah, melainkan di negara-negara dengan mayoritas penduduk non muslim seperti di Amerika Serikat, Inggris, Jerman, Australia dan lain-lain. Ini menjadi bukti bahwa prinsipprinsip yang digunakan oleh Bank Syariah bisa diterima oleh masyarakat non muslim di seluruh dunia. Bahkan bank syariah di Indonesia, negara dengan populasi muslim terbesar di dunia, dimana jumlah nasabah non muslimnya juga sudah cukup banyak (Wahyudi, 2014, hlm.1). Data statistik E\&Y (2013) dalam World Islamic Banking Competetiveness Report 2013-2014 menyebutkan bahwa adanya pertumbuhan dari jumlah aset dan market share di setiap negara. Total aset perbankan syariah telah tumbuh 50\% lebih cepat secara keseluruhan dibeberapa pasar utama industri keuangan. Lebih lanjut menurut E\&Y (2013), pasar internasional yang mempunyai potensi pertumbuhan yang tinggi termasuk Arab Saudi, Malaysia, Qatar, Turki dan Indonesia mengalami pertumbuhan aset di lima tahun terkahir, yaitu pada tahun 2008-2012 tumbuh sebesar $16,4 \%$ atau senilai dengan US $\$ 1.54$ trilliun.

Gambar. 1.1 Grafik Pertumbuhan Aset dan Market Share Perbankan Syariah

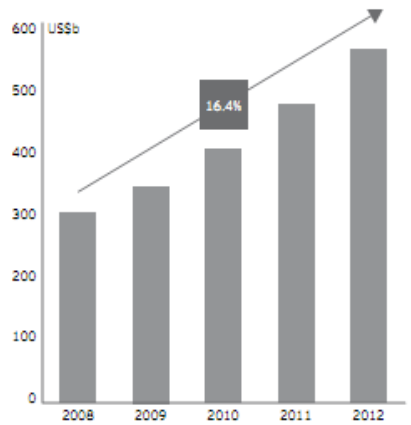

Sumber: Ernst \& Young, 2014

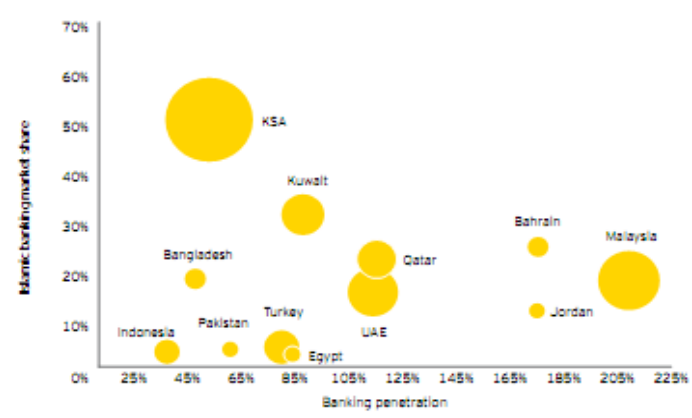

Sumber: Ernst \& Young, 2014

Lebih lanjut data E\&Y (2014) menyebutkan bahwa pertumbuhan aset Bank Syariah pada tahun 2014 sebesar 16.4\%. Aset tersebut sebesar 78\% dimiliki oleh sebagian besar negara-negara Timur Tengah dan Asia seperti Qatar, Indonesia, Saudi Arabia, Malaysia, UAE dan Turkey. Market share Bank Syariah terbesar sampai saat ini adalah Kingdom of Saudi Arabia (KSA) dengan market share menacapai 50\% dari total aset perbankan di negaranya. Sementara itu di Asia Tenggara, Malaysia merupakan termasuk kedalam kelompok negara dengan pertumbuhan market share terbesar di dunia. Keberhasilan sebuah negara seperti Malaysia tidak terjadi secara instan. Sejarah keberadaan perbankan di Malaysia dimulai tahun 1983, bank syariah pertama adalah Bank Islam Malaysia Berhad (BIMB). Menurut data Malaysian International Islamic Financial Centre (MIFC) sampai akhir tahun 2012 terdapat 16 Bank Syariah, terdiri dari 5 stand alone Bank Syariah dan 11 subsidiary dari bank konvensional, yang beroperasi serta menjadi tulang punggung perkembangan Bank Syariah di Malaysia. 
Sebagaimana Malaysia, Indonesia memiliki peran penting dalam pertumbuhan dan perkembangan bank syariah di dunia. Pemerintah Indonesia juga menunjukkan dukungannya terhadap perkembangan perbankan syariah pada tahun 1992 dan secara formal dengan dikeluarkannya UU No. 7 Tahun 1992. Kemudian, pasca ditetapkannya UU No. 21 Tahun 2008 tentang Perbankan Syariah, bank syariah di Indoensia kini memiliki landasan hukum yang jelas. Bank Indonesia menyebutkan bahwa sampai dengan sepetember 2014 jumlah Bank syariah di Indonesia berjumlah 12 buah Bank Umum Syariah (BUS) dan 23 Unit Usaha Syariah (UUS) (Bank Indonesia, 2014).

Selain itu, lebih khusus Indonesia dan Malaysia merupakan kedua negara dengan pertumbuhan aset yang paling signifikan dibandingkan negara-negara lain. Berdasarkan laporan keungan dari kedua negara selama lima tahun terakhir, kinerja perbankan syariah di Indonesia menunjukan perkembangan aset yang mencapai rata-rata 33.4\% pertahun atau senilai USD 12,969 juta. Sementara itu, pertumbuhan aset di Malaysia mencapai rata-rata $16.4 \%$ atau senilai dengan USD 85,978 juta. Lihat tabel di bawah ini (Satuan mata uang menggunakan kurs akhir september tahun 2015).

Tabel. 1.1 Pertumbuhan Aset Perbankan Syariah Indonesia dan Malaysia Tahun 2010 2014 (Dalam Juta)

\begin{tabular}{|c|c|c|c|c|}
\hline Tahun & $\begin{array}{lr}\text { Aset } & \text { Perbankan } \\
\text { Syariah } & \text { Malaysia } \\
\text { (USD) } & \\
\end{array}$ & Persentase & $\begin{array}{lr}\text { Aset } & \text { Perbankan } \\
\text { Syariah } & \text { Indonesia } \\
\text { (USD) } & \\
\end{array}$ & Persentase \\
\hline 2010 & $\$ 59754.51$ & $14.80 \%$ & $\$ 4498.98$ & $47.50 \%$ \\
\hline 2011 & $\$ 74846.07$ & $25.30 \%$ & $\$ 6638.46$ & $49.10 \%$ \\
\hline 2012 & $\$ 85619.02$ & $14.40 \%$ & $\$ 9902.45$ & $34.00 \%$ \\
\hline 2013 & $\$ 98729.93$ & $15.30 \%$ & $\$ 13275.56$ & $24.20 \%$ \\
\hline 2014 & $\$ 110944.69$ & $12.40 \%$ & $\$ 18539.34$ & $12.40 \%$ \\
\hline
\end{tabular}

Sumber: Diolah dari Laporan Keuangan BI dan BNM 2014

Pengukuran kinerja suatu perusahaan di dunia global, termasuk perbankan syariah masih banyak yang menggunakan pengukuran rasio-rasio keuangan seperti CAMELS (Capital, Asset, Management, Earning, Liquidity, Sensitivity of Market Risk), Data Envelopment Analysis (DEA) dan Return on Assets (ROA) dan Return on Equity (ROE). Padahal dalam prakteknya alat ukur konvensional memiliki banyak kelemahan. Pertama, Zaman \& Movassaghi (2002) menyatakan bahwa masih sulit dalam membedakan karakteristik antara bank syariah dengan bank konvensional (hlm.11). Perbedaan ini terjadi akibat adanya perbedaan pandangan tentang keuangan Islam yang mempengaruhi fungsinya sebagai perantara serta kebutuhan untuk menyesuaikan dengan lingkungan dan peraturan lokal (Hawary, Grais, \& Iqbal, 2004, hlm.3). Kedua, banyak dari hasil penelitian yang menyebutkan bahwa dalam mengukur kinerja bank syariah tentu tidak sama dengan mengukur bank konvensional, karena keduanya benar-benar berbeda dalam fungsi inti dan karakteristik operasionalnya (Bedoui, 2012, hlm.7). Ketiga, kondisi ini juga mengindikasikan bahwa tujuan dasar adanya perbankan syariah itu sendiri belum ditangani secara serius, sehingga dalam mengukur kinerja perbankan syariah masih menggunakan alat ukur konvensional yang hanya memfokuskan pada pengukuran finansial. Padahal ada kebutuhan untuk mengembangkan pengukuran kinerja perbankan 
yang sesuai dengan prinsip syariah. Oleh sebab itu, harus ada upaya untuk mengukur kinerja perbankan yang dirumuskan dari sebuah pengukuran berdasarkan prinsip syariah agar ada sebuah alat ukur bagi sebuah bank syariah yang sesuai tujuan syariah (maqashid syariah) (Mohammed, Razak, \& Taib, 2008, hlm.3).

Selain itu, dipertegas oleh Chapra (2000), bahwa perbedaan-perbedaan tersebut merupakan yang paling mendasar. Sehingga, berimplikasi pada perbedaan penciptaan produk kedua model perbankan, termasuk evaluasi kinerja masing-masing perbankan. Umer Chapra menyimpulkan bahwa perbedaan sistem ekonomi Islam dengan ekonomi yang lain terletak pada tiga hal utama: (1) Islamic Wolrdview (pandangan dunia Islam) (2) Tujuan (3) Strategi atau kebijakan (hlm.4). Dalam hal ini, pandangan dunia yang berbeda akan berdampak pada perumusan tujuan bank syariah yang berbeda. Perumusan tujuan yang berbeda akan berdampak pula pada proses perumusan strategi atau model evaluasi yang berbeda pula. Nilai-nilai tersebut tidak hanya diimplementasikan dalam bentuk legalitas fiqh sebuah produk tertentu, akan tetapi harus lebih memiliki dampak yang luas pada aspek ekonomi dan sosial sebagai konsekuensi dari upaya pencapaian maqashid syariah.

Usaha-usaha untuk mengembangkan evaluasi kinerja yang sejalan dengan konsep maqashid syariah pernah dilakukan oleh Mohammed, Dzuljastri, dan Taib (2008), Mohammed \& Taib (2009), Hameed dkk, (2004) dan Shaukat (2008). Hasil penelitian tersebut menyebutkan bahwa praktek pengukuran kinerja dengan pendekatan Maqashid syariah merupakan solusi atas permasalahan yang ada mengenai pengukuran kinerja bagi bank syariah. Selain itu, pengukuruan kinerja bank syariah berdasarkan konsep maqashid syariah ini juga memiliki beberapa kelebihan. Pertama, pengukuran kinerja berdasarkan konsep maqashid syariah merupakan jawaban dari sebuah kebutuhan alat ukur bagi bank syariah itu sendiri. Mengingat konsep maqashid syariah ini menyediakan jawaban yang menghasilkan pengukuran kinerja berdasarkan nilai-nilai Islam sebagai alat ukurnya (Bedoui, 2012, hlm.1). Kedua, hasil pengukuran kinerja bank syariah dapat dilakukan sebagai pendekatan alternatif strategis yang dapat memberikan gambaran kinerja perbankan syariah dengan lebih universal dan dapat diimplementasikan dalam bentuk strategi dan kebijakan yang komprehensif guna tercapainya tujuan syariah dari keberadaan bank syariah tersebut (Mohammed, Razak, \& Taib, 2008, hlm.3). Ketiga, dengan adanya pengukuran kinerja dengan pendekatan maqashid syariah juga menjawab pertanyaan bahwa dalam mengukur kinerja, bank syariah memiliki alat ukur yang berbeda dengan bank konvensional (Mohammed, Razak, \& Taib, 2008, hlm.4).

Sejalan dengan itu, upaya yang dilakukan oleh Mohammed, Razak, \& Taib (2008) merupakan salah satu penelitian yang mengukur kinerja perbankan syariah berdasarkan konsep maqashid syariah. Pengukuran kinerja berdasarkan konsep maqashid syariah dalam penelitian ini juga dikenal dengan maqashid indeks. Melihat terbatasnya penelitian tentang kinerja perbankan syariah dari aspek keuangan yang berdasarkan tujuan syariah (maqashid syariah) secara bersama menjadi ruang bagi penulis untuk mencoba melakukan penelitian ini dengan menggunakan eksplorasi pada tataran pendektan teori yang digunakan dalam mengukur kinerja perbankan syariah yang tentu berbeda dengan pengukuran konvensional pada umumnya. Untuk itu, penelitian ini mencoba menggunakan pendekatan maqashid indeks sebagai salah satu ukuran kinerja bagi perbankan syariah agar diperoleh hasil yang lebih lengkap. 
Jurnal Ekonomi dan Perbankan Syariah

Vol. 3. No.2, 0ctober 2015: 47-66, ISSN (cet): 2355-1755

\section{TELAAH PUSTAKA}

\section{Maqashid Syariah}

Menurut Al Syatibi dalam Fazlulrrahman (1984), secara bahasa maqashid alsyari'ah terdiri dari dua kata, yakni maqashid dan al-syari'ah. Maqashid berarti kesengajaan atau tujuan, sedangkan al-syariah berarti jalan menuju sumber air, dapat pula dikatakan sebagai jalan ke arah sumber pokok kehidupan (hlm.140). Secara terminologi, hukum atau undang-undang yang ditentukan Allah SWT untuk hamba-Nya yang terdapat dalam Al-Qur'an dan diterangkan oleh Rasulullah SAW dalam bentuk sunnahnya (Ismail, 2011, hlm.4). Menurut Zahrah (2011), tujuan syariah (maqashid syariah) adalah segala sesuatu yang ditetapkan oleh Allah dan Rasul-Nya dengan tujuan untuk kemaslahatan manusia secara keseluruhan, yaitu untuk menjaga eksistensi, mengembangkan baik kualitas maupun kuantitas, baik material maupun spiritualnya (hlm.549). Selanjutnya, Abu Zahrah yang membagi maqashid syariah menjadi tiga bagian, yaitu penyucian juwa atau pendidikan, keadilan dan kemaslahatan (Zahrah, 2011, hlm.543-548):

1. Penyucian jiwa, agar setiap muslim bisa menjadi sumber kebaikan bukan sumber keburukan bagi masyarakat lingkungannya. Hal ini ditempuh dari berbagai ragam ibadah yang disyari'atkan, yang kesemuanya dimaksudkan untuk membersihkan jiwa serta memperkokoh kesetiawanan sosial.

2. Keadilan, dalam masyarakat Islam adil baik urusan sesama kaum muslim maupun dalam berhubungan dengan pihak lain (non muslim). Tujuan ditegakkannya keadilan dalam Islam amatlah luhur. Keadilan menyangkut berbagai aspek kehidupan. Dalam hal ini, Islam memandang bahwa setiap orang mempunyai hakhak yang sama, karena Islam mengacu kepada keadilan sosial itu tadi. Dalam usaha mewujudkan keadilan sosial, Islam sangat menjungjung tinggi hak-hak manusia.

3. Kemaslahatan, merupakan ini merupakan tujuan puncak yang hendak dicapai, yang harus terdapat dalam hukum Islam. Tidak sekali-kali suatu perkara disyari'atkan oleh Islam melalui Al-qur'an dan as-sunnah melainkan di situ terkandung maslahat yang hakiki. Maslahat hakiki ini menyangkut semua kepentingan umum, bukan kepentingan pihak tertentu (khusus).

\section{Perbankan Syariah}

Menurut Iqbal (1997), tujuan dari sistem ekonomi Islam yang secara khsusus memberikan penekanan yang sama pada dimensi etika, moral, sosial, dan spiritual dalam upaya meningkatkan keadilan dan pembangunan masyarkat secara keseluruhan. Hal ini menururtnya, sangat berdeda dengan sistem keuangan konvensional yang memusatkan pada aspek transaksi keuangan dan ekonomi saja (hlm.42). Lebih lanjut beliau menjelaskan bahwa, pada tahap awal perbankan syariah tidak bisa disederhanakan dengan bank yang sekedar bebas dari bunga saja. Karena ini merupakan cara yang salah dalam mereduksi bank syariah yang hanya memfokuskan pada transaksi keuangan saja (Iqbal, 1997, hlm.42). Tujuan khusus adanya perbankan syariah selain memberikan jasa keuangan yang halal bagi masyarakat muslim, sistem perbankan syariah diharapkan dapat memberikan kontribusi bagi tercapainya tujuan sosial (kemanusiaan) dari sistem ekonomi Islam. Oleh karena itu, kemunculan lembaga perbankan yang menggunakan nama syariah bukan hanya berdasarkan faktor permintaan pasar semata atau orientasi 
keuangan dan ekonomi saja. Akan tetapi diwujudkan atas dasar nilai-nilai kemanusiaan, yang mampu memecahkan masalah perekonomian yang dialami masyarakat dan sanggup meningkatkan martabat manusianya. Dengan begitu kehahadiran perbankan syariah dengan sendirinya akan mampu membawa perubahan perekonomian masyarakat muslim ke arah yang jauh lebih baik (Purwanda \& Muttaqien, 2012, hlm.8).

Perbankan syariah dalam peristilahan Internasional juga dikenal dengan Islamic Banking atau disebut juga dengan Interset-fee banking. Dalam istilah ini Bank syariah tidak dapat dilepaskan dari asal usul sistem perbankan syariah itu sendiri, karena pada dasarnya bank syariah dikembangkan dengan menggabungkan antara masalah-masalah duniawi dengan agama. Sehingga dasar tersebut mengharuskan kepatuhan kepada syariat sebagai dasar kehidupan dengan tujuan mendapatkan ridha dari Allah untuk memperoleh kebaikan dunia dan akhirat. Oleh karena itu apa yang dijalankan dalam praktek perbankan pun merupakan salah satu aspek muamalah yang harus sesuai dengan syariat Islam yaitu Al-Qur'an dan Hadits (Ginanjar, 2013, hlm.11). Menurut Chapra (2001), bahwa salah satu aspek muamalah dalam ekonomi Islam yang wajib dihindari adalah praktek riba. Oleh sebab itu, sistem perbankan yang menjalankan praktek ribawi (bunga/interst) dilarang oleh syariat Islam karena merugikan salah satu pihak, bahkan cenderung mengarah pada ketidakadilan. Ketidakadilan ini menurutnya tidak sejalan dengan tujuan adanya syariat Islam (hlm.12).

\section{Kinerja Bank Berdasarkan Maqashid Syariah}

Menurut Hameed dkk (2004), kinerja dapat diartikan sebagai suatu metode untuk mengukur pencapaian perusahaan berbasis pada target-target atau tujuan yang diususun dari awal. Hal ini menjadi bagian penting dari kontrol pengukur yang dapat membantu perusahaan atau organisasi dalam memperbaiki kinerjanya di masa mendatang. Menurut Bedoui (2012), tujuan bank syariah sendiri merupakan aplikatif dari penerapan prisnsip syariah. Dalam hal ini kinerja merupakan konsekuensi dan hasil dari tujuan yang telah ditetapkan sebelumnya. Oleh sebab itu, tujuan yang dimaksud merupakan parameter yang penting dalam menilai seberapa baik pencapaian kinerja bank syariah (hlm.5). Untuk menilai atau mengukur kinerja juga dibutuhkan metode yang tepat. Sehingga capaian atas kinerja dapat disesuaikan dengan tujuan yang telah ditentukan sebelumnya oleh bank syariah itu sendiri.

Lebih khusus, Yuliani (2012) berpendapat bahwa saat ini kinerja bank syariah lebih banyak berfokus pada kinerja keuangan atau berbasis profit oriented. Sehingga, beberapa pakar perbankan syariah internasional telah melakukan penelitian yang mengukur kinerja bank syariah dengan lebih komprehensif (hlm.16). Oleh sebab itu, dalam mengukur kinerja perbankan syariah bukan sekedar dari indikator rasio keuangan saja, melainkan adanya kebutuhan untuk mengukur kinerja berdasarkan tujuan bank syariah itu sendiri. Indikator kinerja perbankan syariah harus memperhatikan kemaslahatan umat, dimana Islam telah mengatur bahwa kegiatan muamalah harus dilaksanakan sesuai dengan prinsip syariah, yaitu dengan memahami tujuan-tujuan syariah (maqasid syariah) (Mohammed, Razak, \& Taib, 2008, hlm.4).

Berdasarkan penelitian sebelumnya, ada dua macam pengukuran kinerja bank berdasarkan maqashid syariah, yaitu pengukuran kinerja bank berdasarkan Shariah Conformity and Profitablity (SCnP) Model dan pengukuran kinerja bank berdasarkan Maqoshid Indeks. 


\section{Shariah Conformity and Profitablity (SCnP) Model}

Upaya mengembangkan pengukuran kinerja bank syariah yang berdasarkan prinsip maqashid syariah pernah dilakukan oleh Kuppusamy (2010), yaitu penelitian dengan mengukur kinerja bank syariah menggunakan Shariah Conformity and Profitablity (SCnP) Model. SCnP ini merupakan salah satu model penilaian kinerja keuangan pada perbankan, khususnya pada perbankan syariah. Dimana model ini menggabungkan orientasinya pada indikator profitabilitas yang digunakan untuk menilai kinerja keuangan konvensional dengan orientasi indeks kesesuaian terhadap sistem syariah untuk menilai sosio-ekonomi kewajiban bank syariah. Adapun variabel berdasrkan syariah terdiri dari rasio investasi syariah, pendapatan syariah, dan rasio bagi hasil. Sedangkan variabel dari profitabilitas terdiri dari ROA, ROE, dan profit margin (Kuppusamy, 2010, hlm.35-48).

\section{Maqashid Indeks}

Mohammed dkk (2008) telah mengembangkan evaluasi kinerja untuk perbankan syariah berdasarkan maqashid indeks yang merujuk pada konsep maqashid syariah Abu Zahrah. Maqashid indeks ini terbagi menjadi 3 variabel yaitu Pendidikan Individu (Tahdzib al-Nafs), Establishing justice (Iqamah Al-Adl), dan Maslahah (Welfare). Kemudian, dari 3 variabel tersebut ditransformasikan menjadi sepuluh rasio kinerja (hlm.6-16):

Gambar. 3.2 Pengukuran Kinerja Bank Berdasarkan Maqashid Indeks

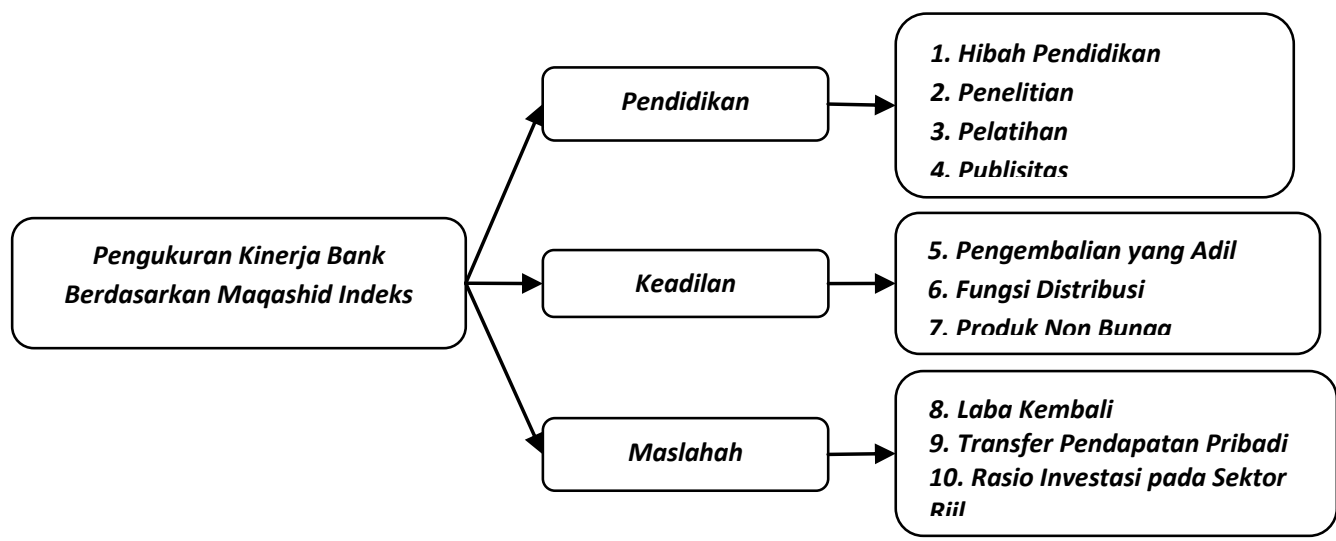

Sumber: Diolah dari Mohammed dkk, 2008

1. Education The Individual (Pendidikan Individu), dimaksudkan bahwa bank syariah harus melakukan pengembangan pengetahuan dan keahlian pada individu sehingga nilai-nilai spiritual meningkat. Dalam hal ini, agar setiap muslim bisa menjadi sumber kebaikan bukan sumber keburukan bagi masyarakat lingkungannya. Untuk itu pendidikan ini terbagi menjadi dua, yaitu pendidikan bagi pihak internal dan eksternal bank syariah. Dalam hal ini, dimana Pendidikan atau Beasiswa, Research (Penelitian), dan Training (Pelatihan) merupakan bagian pendidikan yang dilakukan bank syariah bagi karyawan (Internal) dan Publicity (Iklan) merupakan edukasi atau 
pendidikan bagi masyarakat (Eksternal). Selanjutnya, variabel yang pertama ini terdiri dari empat rasio (Mohammed dkk, 2008, hlm.6-7).

2. Justice (Keadilan) dimaksudkan bahwa bank syariah harus memastikan kejujuran dan keadilan dalam setiap transaksi dan aktivitas bisnis yang tercakup dalam produk, pricing, dan ketentuan-ketentuan kontrak. Di samping itu, seluruh akadakad harus bebas dari unsur-unsur ketidakadilan seperti maysir, gharar, dan riba. Oleh sebab itu, variabel yang kedua ini terbagi menjadi tiga rasio, yaitu Fair Return, Funcional Distribution, dan Interest free Product (Mohammed dkk, 2008, hlm.7).

3. Maslahah (Kesejahteraan), dimaksudkan bahwa bank syariah harus mengembangkan proyek-proyek investasi dan jasa sosial untuk meningkatkan kesejahteraan masyarakat. Karena Maslahah (kesejahteraan) merupakan aspek penting bagi kehidupan manusia, sehingga aspek ini turut menjadi perhatian yang utama khususnya dalam industri perbankan syariah. Maslahah (Kesejahteraan) ini juga selain memberikan manfaat bagi masyarakat, juga memberikan manfaatnya pada bank syariah itu sendiri. Selanjutnya, variabel yang ketiga ini terbagi menjadi tiga rasio, yaitu Profit Return, Personal Income Transfer (Zakat), dan Investment In Real Sector (Mohammed dkk, 2008, hlm.13).

Dalam penelitian ini, penulis menggunakan pengukuran kinerja bank berdasarkan maqshid indeks, karena pengukuran kinerja berdasarkan maqashid indeks ini dalam merepresentasikan kinerja bank berdasarkan nilai-nilai Islam (maqashid syariah) dengan lebih komprehensif. Sedangkan, pengukuran kinerja bank berdasarkan Shariah Conformity and Profitablity (SCnP) Model masih mengadopsi pengukuran berdasarkan rasio konvensional sehingga belum mampu mepresentasikan aspek kesyariahannya secara keseluruhan.

\section{Penelitian Terdahulu}

Mohammed, Dzuljastri, dan Taib (2008) dalam penelitiannya yang berjudul The Performance Measures of Islamic Banking Based on the Maqasid Framework. Konsep Maqashid Indeks dikembangkan dengan menggunakan metode SAW (The Simple Additive Weighting). Terdapat enam sampel perbankan syariah (Bank Muamalat Malaysia, Islamic Bank Bangladesh, BSM Indonesia, Bahrain Islamic Bank, JIIAB Jordan, dan Sudanese Islamic Bank) yang menjadi objek penelitian dalam rentang waktu enam tahun (20002005). Variabel yang digunakan merujuk pada teori Maqashid Syariah Abu Zahrah yang meliputi Tahdzib al-Fard, Iqamah Al-Adl dan Maslahah. Hasil penelitian menunjukkan bahwa JIIAB Jordan menempati ranking tertinggi, setelah itu disusul oleh BSM Indonesia, Bahrain Islamic Bank, Islamic Bank Bangladesh, Bank Muamalat Malaysia dan terakhir Sudanese Islamic Bank.

Kuppusamy, Saleha dan Samudhram (2010) juga turut mengevaluasi kinerja perbankan syariah dalam penelitiannya yang berjudul Measurement of Islamic Banks Performance Using a Shariah Conformity and Profitablity Model, mengambil sampel empat bank yaitu Malaysia, Bahrain, Kuwait and Jordan dari tahun 2001-2004. Model yang dikembangkan dinamakan Shariah Conformity and Profitability (SCnP) Hasil menunjukkan bahwa mayoritas perbankan syariah mampu mencapai profitabilitas yang tinggi dan shariah compliance yang baik. Namun, terdapat satu bank yang memiliki tingkat profitabilitas dan shariah compliance yang rendah. 
Taufik dan Hilman (2012) dalam penelitiannya yang berjudul Model Penilaian Tingkat Kesehatan Perbankan Syariah: Implementasi Maqasid Indeks Di Indonesia Dan Yordania, dengan mengambil 4 sampel bank yang ada di Indonesia dan Yordania (BSM, BMI, Islamic International Arab Bank, dan Jordan Islamic Bank) periode 2008 - 2010, hasil penelitian mereka menempatkan BMI memiliki kinerja yang lebih baik dari ketiga bank lainnya dengan pendekatan maqoshid indeks.

Terakhir oleh Luqman dkk (2013) dalam penelitiannya yang berjudul The Performance Measure of Selected Malaysian and Indonesia Islamic Banks based on the Maqasid al-Shari'ah Approach. Penelitian ini menggunakan pendekatan PMMS langkahlangkah kinerja yang dipilih tiga bank Islam Indonesia yaitu Bank Muamalat Indonesia, Bank Syariah Mandiri dan Bank Mega Syariah dan tiga bank Islam Malaysia yaitu RHB bank Islam, CIMB Bank Islam dan Bank Islam selama periode 2007-2011. Hasil penelitian menunjukkan kinerja tertinggi berdasarkan maqashid indeks tidak lebih dari 35\% yatu Bank Muamalat Indonesia dan terendah adalah 17.18\% terjadi di CIMB Islamic Bank.

\section{METODE PENELITIAN}

\section{Sumber Data Penelitian}

Data yang digunakan dalam penelitian ini merupakan data sekunder yang diambil dari laporan keuangan tahunan yang bersumber dari situs resmi masing-masing bank syariah berdasarkan aset terbesar selama tahun 2011-2014 dan ditambah dengan situs resmi kedua perbankan (BI dan BNM). Dengan demikian, maka terdapat 8 bank syariah dari kedua negara yang terdiri dari 4 bank syariah di Indonesia (Bank Syariah Mandiri, Bank Muamalat Indonesia, Bank Rakyat Indonesia Syariah dan Bank Negara Indonesia Syariah) dan 4 bank syariah di Malaysia (Bank Islam Malaysia Berhad, CIMB Islamic Bank Berhad, Maybank Islamic Berhad dan RHB Islamic Bank Berhad).

\section{Instrumen Penelitian}

Berdasarkan penelitian sebelumnya, penulis menggunakan variabel maqashid indeks yang telah diteliti oleh Mohammed dkk (2008). Berikut di bawah ini ialah aplikasi tujuan perbankan syariah berdasarkan maqashid indeks yang diambil untuk memenuhi penelitian:

Tabel. 3.1 Aplikasi Tujuan Perbankan Syariah Berdasarkan Maqashid Indeks

\begin{tabular}{|l|l|l|l|l|}
\hline Konsep & Dimensi & Elemen & Rasio kinerja & Sumber \\
\hline \multirow{7}{*}{$\begin{array}{l}\text { Pendidikan } \\
\text { Individu }\end{array}$} & $\begin{array}{l}\text { D1. Meningkatkan } \\
\text { Pengetahuan }\end{array}$ & $\begin{array}{l}\text { E1.Hibah } \\
\text { Pendidikan }\end{array}$ & $\begin{array}{l}\text { R1. Hibah Pendidikan/ } \\
\text { Total Biaya }\end{array}$ & $\begin{array}{l}\text { Laporan } \\
\text { Tahunan }\end{array}$ \\
\cline { 2 - 5 } & $\begin{array}{l}\text { meningkatkan } \\
\text { kemampuan baru }\end{array}$ & E2. Penelitian & $\begin{array}{l}\text { R2. Biaya } \\
\text { penelitian/Total Biaya }\end{array}$ & $\begin{array}{l}\text { Laporan } \\
\text { Tahunan }\end{array}$ \\
\cline { 2 - 5 } & $\begin{array}{l}\text { D3. Menciptakan } \\
\text { Kesadaran } \\
\text { Masyarakat akan } \\
\text { Keberadaan Bank } \\
\text { Syariah }\end{array}$ & E4. Publisitas & $\begin{array}{l}\text { R3. Biaya } \\
\text { Pelatihan/Total Biaya }\end{array}$ & $\begin{array}{l}\text { Laporan } \\
\text { Tahunan }\end{array}$ \\
\hline
\end{tabular}


56 | AL-Ghifari, Handoko \& Yani: Analisis Kinerja Perbankan Syariah Di Indonesia Dan Malaysia.........

\begin{tabular}{|c|c|c|c|c|}
\hline \multirow{3}{*}{$\begin{array}{l}\text { Menciptakan } \\
\text { Keadilan }\end{array}$} & D4. Kontrak yang Adil & $\begin{array}{l}\text { E5. } \\
\text { Pengembalian } \\
\text { yang Adil } \\
\end{array}$ & $\begin{array}{l}\text { R5. Profit Equalization } \\
\text { Reserves (PER)/Net or } \\
\text { Investment Income }\end{array}$ & $\begin{array}{l}\text { Laporan } \\
\text { Tahunan }\end{array}$ \\
\hline & $\begin{array}{l}\text { D5.Produk dan } \\
\text { Layanan Terjangkau }\end{array}$ & $\begin{array}{l}\text { E6. Fungsi } \\
\text { Distribusi }\end{array}$ & $\begin{array}{l}\text { R6. Mudharabah dan } \\
\text { Musharakah/ Total } \\
\text { Pembiayaan }\end{array}$ & $\begin{array}{l}\text { Laporan } \\
\text { Tahunan }\end{array}$ \\
\hline & $\begin{array}{l}\text { D6. Penghapusan } \\
\text { Ketidakadilan }\end{array}$ & $\begin{array}{l}\text { E7. Produk Non } \\
\text { Bunga }\end{array}$ & $\begin{array}{l}\text { R7. Pendapatan Non } \\
\text { Bunga /Total } \\
\text { Pendapatan }\end{array}$ & $\begin{array}{l}\text { Laporan } \\
\text { Tahunan }\end{array}$ \\
\hline \multirow{3}{*}{$\begin{array}{l}\text { Kepentingan } \\
\text { Umum }\end{array}$} & D7. Profitabilitas & E8. Rasio Laba & $\begin{array}{l}\text { R8. Laba Bersih/Total } \\
\text { Aset }\end{array}$ & $\begin{array}{l}\text { Laporan } \\
\text { Tahunan }\end{array}$ \\
\hline & $\begin{array}{l}\text { D8. Pendistribusian } \\
\text { kekayaan \& Laba }\end{array}$ & $\begin{array}{l}\text { E9. Pendapatan } \\
\text { Personal }\end{array}$ & R9. Zakat/Net Aset & $\begin{array}{l}\text { Laporan } \\
\text { Tahunan }\end{array}$ \\
\hline & $\begin{array}{l}\text { D9. Investasi pada } \\
\text { Sektor Riil yang Vital }\end{array}$ & $\begin{array}{l}\text { E10. Rasio } \\
\text { Investasi pada } \\
\text { Sektor Riil }\end{array}$ & $\begin{array}{l}\text { R10. Penyaluran } \\
\text { Investasi pada Sektor } \\
\text { Riil/ Total Penyaluran } \\
\text { Investasi }\end{array}$ & $\begin{array}{l}\text { Laporan } \\
\text { Tahunan }\end{array}$ \\
\hline
\end{tabular}

Sumber: Mohammed dkk, 2008

\section{Pembobotan Kinerja}

Model Maqashid Indeks yang dikembangkan oleh Mohammed dkk (2008) ini telah diteliti oleh para ahli di Timur Tengah dan Malaysia yang berpengalaman di Bank Konvensional dan Syariah. Penelitian ini menggunakan pendekatan metode SAW (The Simple Additive Weighting) adalah sebuah metode yang mengharuskan pembuat keputusan menentukan bobot bagi setiap atribut/acuan. Bobot rata-rata yang diberikan oleh para ahli dapat dilihat di tabel di bawah ini.

Tabel. 3. 2 Aplikasi Bobot Rata-Rata Variabel Maqashid Indeks

\begin{tabular}{|l|l|l|l|}
\hline $\begin{array}{l}\text { Konsep } \\
\text { (Objectives) }\end{array}$ & $\begin{array}{l}\text { Average Weight } \\
(100 \%)^{*}\end{array}$ & \multicolumn{1}{|c|}{ Elemen } & $\begin{array}{l}\text { Average Weight } \\
(100 \%)\end{array}$ \\
\hline \multirow{4}{*}{$\begin{array}{l}\text { 1. Pendidikan } \\
\text { Individu }\end{array}$} & \multirow{4}{*}{30} & R1.Donasi Pendidikan & 24 \\
\cline { 3 - 4 } & & R2. Penelitian & 27 \\
\cline { 3 - 4 } & & R3.Pelatihan & 26 \\
\cline { 3 - 4 } & & R4. Publikasi & 23 \\
\cline { 3 - 4 } $\begin{array}{l}\text { 2. Menciptakan } \\
\text { Keadilan }\end{array}$ & \multirow{4}{*}{41} & Total & 100 \\
\hline \multirow{4}{*}{$\begin{array}{l}\text { 3. Kepentingan } \\
\text { Publik }\end{array}$} & \multirow{3}{*}{29} & R5. Pengembalian yang Adil & 30 \\
\cline { 3 - 4 } & & R6. Fungsi Distribusi & 32 \\
\cline { 3 - 4 } & & R7. Produk Bebas Bunga & 38 \\
\cline { 3 - 4 } & & Total & 100 \\
\hline Total & R8. Rasio Profit & 30 \\
\cline { 3 - 4 } & & R9. Pendapatan Personal & 33 \\
\cline { 3 - 4 } & & R10. Investasi di Sektor Riil & 37 \\
\cline { 3 - 4 } & & Total & 100 \\
\hline
\end{tabular}

Sumber: Mohammed, Razak, \& Taib, 2008 


\section{Penentuan Rasio Kinerja}

Dalam langkah ini, terdapat empat rasio terkait dengan PI (01) tujuan Pendidikan, tiga rasio pada PI (02) tujuan Keadilan dan tiga rasio dari PI (03) tujuan Maslahah. Secara keseluruhan terdapat sepuluh rasio kinerja yang diidentifikasi, akan tetatapi di dalam penelitian ini hanya akan menggunakan dealapan rasio kinerja dari ketiga tujuan PI tersebut. Sementara itu, dari tiga rasio PI (02) tujuan keadilan, penulis tidak menggunakan rasio Pengembalian yang Adil/profit equalization reserve (PER) dan Produk Bebas Bunga/interest free income, karena kedua data tersebut tidak tersedia pada Laporan Tahunan yang dipublikasikan ke delapan bank syariah yang dijadikan objek penelitian. Berikut dibawah ini ke delapan rasio yang akan digunakan dalam penelitian:

1. Donasi Pendidikan/total biaya (R11)

2. Biaya Penelitian/total biaya $\left(\mathrm{R} 1^{2}\right)$

3. Biaya Pelatihan/total biaya $\left(\mathrm{R} 1^{3}\right)$

4. Biaya Publikasi/total biaya (R14)

5. Pembiayaan Mudharabah and Musyarakah/total pembiayaan (R21)

6. Net income/Total aset (R3 $\left.{ }^{1}\right)$

7. Dana Zakat/Net Aset $\left(\mathrm{R}^{2}\right)$

8. Investasi di Sektor Riil/Total Investasi (R333)

\section{Langkah-langkah Pengujian Maqashid Indeks}

Pengukuran kinerja dengan Maqashid Indeks ada beberapa pengujian, setelah penentuan ke 8 rasio kinerja, selanjutnya menghitung kinerja Maqashid Indeks (MI). Dimana MI merupakan hasil dari penjumlahan seluruh indikator kinerja, yang terdiri dari (PI) tujuan 1, (PI) tujuan 2 dan (PI) tujuan 3. Dengan demikian, MI merupakan keseluruhan dari perhitungan Maqashid Indeks. Selanjutnya, dinotasikan sebagai berikut: MI = Pi (01) + PI (02) + PI (03)

Dimana, MI= Hasil maqashid indeks keseluruhan, PI (01) = Hasil dari Education, PI (02) = Hasil dari Justice, PI (O3) = Hasil dari Maslahah

\section{HASIL DAN ANALISIS}

\section{Analisis Data}

Data di Indonesia terdapat 4 bank syariah yang memiliki aset terbesar, yaitu Bank Syariah Mandiri (BSM), Bank Muamalat Indonesia (BMI), Bank Rakyat Indonesia Syariah (BRIS) dan Bank Negara Indonesia Syariah (BNIS). Sementara itu, di Malaysia terdapat Maybank Islamic Berhad (MIB), CIMB Islamic Berhad (CIMBiB), Bank Islam Malaysia Berhad (BIMB) dan RHB Islamic Bank (RHBiB). Adapun tabel perkembangan aset perbankan syariah di Indonesia dan Malaysia dari tahun 2011-2014 bisa dilihat pada tabel di bawah ini.

Tabel. 5.1 Perkembangan Aset Perbankan Syariah di Indonesia 2011-2014

\begin{tabular}{|c|l|l|l|l|}
\hline $\begin{array}{c}\text { Nama } \\
\text { Bank }\end{array}$ & \multicolumn{1}{|c|}{2011} & \multicolumn{1}{|c|}{2012} & \multicolumn{1}{|c|}{2013} & \multicolumn{1}{|c|}{2014} \\
\hline & Rp48,671,950,025, & Rp54,229,395,784, & Rp63,965,361,177, & Rp66,942,422,284, \\
BSM & 000.00 & 000.00 & 000.00 & 791.00 \\
\hline & Rp32,479,506,528, & Rp44,854,413,084, & Rp54,694,020,564, & Rp62,413,310,135, \\
000.00 & 000.00 & 000.00 \\
BMI & 000.00 & 0
\end{tabular}


58 | AL-Ghifari, Handoko \& Yani: Analisis Kinerja Perbankan Syariah Di Indonesia Dan Malaysia.

\begin{tabular}{|c|l|l|l|l|} 
& Rp11,200,823,000, & Rp14,088,914,000, & Rp17,400,914,000, & Rp20,343,249,000, \\
BRIS & 000.00 & 000.00 & 000.00 & 000.00 \\
\hline & Rp8,466,887,000,0 & Rp10,645,313,000, & Rp14,708,504,000, & Rp19,492,112,000, \\
BNIS & 00.00 & 000.00 & 000.00 & 000.00 \\
\hline
\end{tabular}

Sumber: data diolah dari BI

Tabel. 5.2 Perkembangan Aset Perbankan Syariah di Malaysia 2011-2014

\begin{tabular}{|l|l|l|l|l|}
\hline $\begin{array}{l}\text { Nama } \\
\text { Bank }\end{array}$ & $\mathbf{2 0 1 1}$ & $\mathbf{2 0 1 2}$ & $\mathbf{2 0 1 3}$ & $\mathbf{2 0 1 4}$ \\
\hline & RM75,512,938,0 & RM91,432,370,0 & RM125,056,697,0 & RM146,394,406,0 \\
MIB & 00.00 & 00.00 & 00.00 & 00.00 \\
\hline CIMBi & RM43,097,758,0 & RM51,225,040,0 & RM49,423,178,00 & RM49,863,771,00 \\
B & 00.00 & 00.00 & 0.00 & 0.00 \\
\hline & RM32,226,504,0 & RM37,450,798,0 & RM42,836,531,00 & RM45,829,287,00 \\
BIMB & 00.00 & 00.00 & 0.00 & 0.00 \\
\hline RHBi & RM22,641,412,0 & RM25,609,662,0 & RM29,131,089,00 & RM36,113,786,00 \\
B & 00.00 & 00.00 & 0.00 & 0.00 \\
\hline
\end{tabular}

Sumber: data diolah dari BNM

Berdasarkan data tabel di atas, perkembangan aset BNIS dan MIB merupakan yang terbesar selama tahun 2011-2014. Keduanya mengalami perkembangan aset yang memuaskan, yaitu masing-masing sebesar 32.1\% dan 25\%. Sementara itu, dua bank syariah yang perkembangan asetnya paling rendah adalah BSM dan CIMBiB, yaitu masing-masing hanya mencapai perkembangan $11.3 \%$ dan $5.4 \%$. Selain itu, secara keseluruhan perbankan syariah di Indonesia dan Malaysia mencapai angka 5-25\% di setiap tahun. Peningkatan aset dari suatu industri keuangan memberikan indikasi tentang peningkatan kinerja industri tersebut, akan tetapi indikator tersebut hanyalah salah satu gambaran kinerja perbankan saja dan belum mewakili secara keseluruhan. Oleh sebab itu, perbankan syariah perlu memiliki gambaran kinerja secara menyeluruh yang sesuai dengan tujuan utamanya yaitu maqashid syariah.

\section{Rasio Kinerja Maqashid Indeks Indonesia dan Malaysia}

Tabel. 5.3 Rasio Kinerja Perbankan Syariah di Indonesia dan Malaysia 2011-2014

\begin{tabular}{|c|c|c|c|c|c|c|c|c|c|}
\hline Elemen & $\begin{array}{c}\text { Ras } \\
\text { io }\end{array}$ & BMI & BSM & BRIS & BNIS & MIB & $\begin{array}{c}\text { BIM } \\
\text { B }\end{array}$ & CIMB & $\begin{array}{c}\text { RHBi } \\
\text { B }\end{array}$ \\
\hline $\begin{array}{c}\text { Donasi } \\
\text { Pendidikan/Beasiswa }\end{array}$ & R11 & $\begin{array}{c}0.91 \\
\%\end{array}$ & $\begin{array}{c}0.30 \\
\%\end{array}$ & $\begin{array}{c}0.00 \\
\%\end{array}$ & $\begin{array}{c}0.39 \\
\%\end{array}$ & $\begin{array}{c}0.38 \\
\%\end{array}$ & $\begin{array}{c}0.23 \\
\%\end{array}$ & $\begin{array}{c}0.17 \\
\%\end{array}$ & $\begin{array}{c}0.11 \\
\%\end{array}$ \\
\hline Penelitian & $\mathbf{R 1}^{2}$ & $\begin{array}{c}0.23 \\
\%\end{array}$ & $\begin{array}{c}0.11 \\
\%\end{array}$ & $\begin{array}{c}0.00 \\
\%\end{array}$ & $\begin{array}{c}0.00 \\
\%\end{array}$ & $\begin{array}{c}0.00 \\
\%\end{array}$ & $\begin{array}{c}0.70 \\
\%\end{array}$ & $\begin{array}{c}0.31 \\
\%\end{array}$ & $\begin{array}{c}0.00 \\
\%\end{array}$ \\
\hline Pelatihan & $\mathbf{R 1}^{3}$ & $\begin{array}{c}1.45 \\
\%\end{array}$ & $\begin{array}{c}1.52 \\
\%\end{array}$ & $\begin{array}{c}1.53 \\
\%\end{array}$ & $\begin{array}{c}3.90 \\
\%\end{array}$ & $\begin{array}{c}1.57 \\
\%\end{array}$ & $\begin{array}{c}0.60 \\
\%\end{array}$ & $\begin{array}{c}0.44 \\
\%\end{array}$ & $\begin{array}{c}0.60 \\
\%\end{array}$ \\
\hline Publisitas & $\mathbf{R 1}^{4}$ & $\begin{array}{c}4.14 \\
\%\end{array}$ & $\begin{array}{c}3.03 \\
\%\end{array}$ & $\begin{array}{c}2.54 \\
\%\end{array}$ & $\begin{array}{c}6.45 \\
\%\end{array}$ & $\begin{array}{c}0.86 \\
\%\end{array}$ & $\begin{array}{c}0.68 \\
\%\end{array}$ & $\begin{array}{c}0.53 \\
\%\end{array}$ & $\begin{array}{c}1.87 \\
\%\end{array}$ \\
\hline Fungsi Distribusi & $\mathbf{R}^{2}$ & $\begin{array}{c}47.97 \\
\%\end{array}$ & $\begin{array}{c}13.78 \\
\%\end{array}$ & $\begin{array}{c}25.92 \\
\%\end{array}$ & $\begin{array}{c}13.66 \\
\%\end{array}$ & $\begin{array}{c}6.85 \\
\%\end{array}$ & $\begin{array}{c}0.01 \\
\%\end{array}$ & $\begin{array}{c}0.50 \\
\%\end{array}$ & $\begin{array}{c}21.15 \\
\%\end{array}$ \\
\hline Profitabilitas & R31 $^{1}$ & $\begin{array}{c}0.67 \\
\%\end{array}$ & $\begin{array}{c}0.94 \\
\%\end{array}$ & $\begin{array}{c}0.40 \\
\%\end{array}$ & $\begin{array}{c}0.84 \\
\%\end{array}$ & $\begin{array}{c}1.70 \\
\%\end{array}$ & $\begin{array}{c}3.36 \\
\%\end{array}$ & $\begin{array}{c}1.95 \\
\%\end{array}$ & $\begin{array}{c}1.55 \\
\%\end{array}$ \\
\hline $\begin{array}{c}\text { Pendapatan } \\
\text { Personal/Zakat }\end{array}$ & R3 $^{2}$ & $\begin{array}{c}0.04 \\
\%\end{array}$ & $\begin{array}{c}0.06 \\
\%\end{array}$ & $\begin{array}{c}0.04 \\
\%\end{array}$ & $\begin{array}{c}0.06 \\
\%\end{array}$ & $\begin{array}{c}0.27 \\
\%\end{array}$ & $\begin{array}{c}0.30 \\
\%\end{array}$ & $\begin{array}{c}0.08 \\
\%\end{array}$ & $\begin{array}{c}0.05 \\
\%\end{array}$ \\
\hline Investasi di Sektor & R3 $^{3}$ & 76.06 & 89.62 & 79.89 & 73.42 & 67.21 & 84.80 & 62.20 & 67.70 \\
\hline
\end{tabular}




\begin{tabular}{|l|l|l|l|l|l|l|l|l|l|} 
Riil & & $\%$ & $\%$ & $\%$ & $\%$ & $\%$ & $\%$ & $\%$ & $\%$ \\
\hline
\end{tabular}

Sumber: data diolah

\section{Rasio Kinerja Maqashid Indeks Tujuan Pertama (Education/Tahdzib Al fard)}

a) Donasi Pendidikan/Total Biaya

Berdasarkan hasil perhitungan dari tahun 2011-2014, bank syariah yang paling konsen dalam hal pemberian donasi pendidikan kepada masyarakat adalah BMI. Secara kumulatif BMI dinilai terbaik karena memiliki nilai tertinggi, yaitu mencapai $0.91 \%$. Sementara itu, BRIS menempati urutan terendah, karena tidak adanya alokasi dana untuk donasi pendidikan selama tahun penelitian. Dengan angka tersebut, tingginya rasio kinerja donasi pendidikan yang diperoleh BMI dari tahun 2011-2014 juga sejalan dengan kontribusi BMI di bidang pendidikan. BMI berkerjasama dengan memberikan donasi pendidikan ke beberapa universitas/institusi sebagai salah satu upaya untuk berkontribusi di dunia pendidikan Indonesia (Laporan Tahunan BMI, 2014). Sehingga, selain bermanfaat bagi dunia pendidikan, namun juga menjadi akses bagi bank tersebut dalam memenuhi kebutuhan sumber daya insani pada bank itu sendiri. Selain itu, tujuan adanya alokasi dana yang disalurkan dalam bentuk program-program donasi pendidikan merupakan konsep dari hifzul aql (penjagaan terhadap akal) yang sesuai dengan konsep maqashid syariah.

\section{b) Biaya Penelitian/total biaya $\left(R 1^{2}\right)$}

Rasio kinerja tujuan pertama tentang penelitian terlihat bahwa, BIMB memperoleh nilai tertinggi yaitu $0.70 \%$. Sementara itu, BSM dan BMI menjadi dua bank syariah yang rasio kinerja paling rendah. Kedua bank tersebut memiliki nilai rata-rata tidak lebih dari $0.25 \%$. Sementara itu, BRIS dan BNIS menjadi yang terendah, karena kedua bank tersebut tidak mengalokasikan dana untuk penelitian selama tahun 2011-2014. Melihat hanya empat bank syariah yang memengalokasikan dananya untuk penelitian dan hanya memperoleh nilai tertinggi tidak lebih dari $0.70 \%$ sebagai pertanda bahwa perbankan syariah baik di Indonesia dan Malaysia perlu lebih memperhatikan kembali tujuan adanya alokasi dana untuk riset/penelitian. Selain itu, persaingan industri perbankan di masing-masing negara yang sedemikian ketat, tentu menuntut bank syariah untuk berinovasi agar kedepan memiliki keunggulan dan kemampuan dalam menciptakan hal yang baru. Salah satu bukti komitemen bank syariah terhadap konsistensi dan keberlanjutannya dilihat dari aloakasi sumber daya untuk program riset dan pengembangannya. Dengan demikian, bank syariah baru bisa dikatakan sejalan dengan konsep maqashid syariah (hifzul 'aql) jika memperhatikan dan memiliki alokasi lebih utnuk penelitian.

c) Biaya Pelatihan/total biaya $\left(R 1^{3}\right)$

Hasil perhitungan menunjukkan bahwa, BNIS merupakan bank syariah yang paling konsen dalam hal peningkatan kualitas karyawan melalui pelatihan. BNIS memeproleh nilai rasio sebesar $3.90 \%$. Sementara itu, CIMB Islamic menjadi yang terendah dengan nilai $0.44 \%$. Dengan hasil tersebut, penulis menilai BNIS lebih baik tingkat keberlanjutannya, karena telah berusaha mengaplikasikan rumusan tentang jaminan keberlanjutan perusahaan dari aspek pelatihan. Hal ini terbukti dengan 3 kategori 
program pelatihan yang dijalankan oleh BNIS sejak tahun 2011. Pertama, pelatihan dalam bentuk hard skill, seperti program Pengembangan HRIS (Human Resources Information Sharia). Kedua, pelatihan dalam bentuk setifikasi seperti program Certified Career and Talent management Specialist berupa Program Training \& Development Officer (ODP). Dan terakhir, pelatihan dalam bentuk soft skill seperti program Team Building and Motivation (Laporan Tahunan BNIS, 2014). Implementasi dari program-program tersebut juga sejalan dengan konsep hifzul aql (penjagaan terhadap akal) dan hifzhun nafs (penjagaan terhadap jiwa). Selain itu, adanya program-program tersebut diharapakan agar semua karyawan bank syariah dapat memahami secara baik karakteristik dan pola kerja perbankan syariah. Sehingga, kepatuhan terhadap prosedur kerja dan kepatuhan terhadap syariah (sharia compliance) tetap terjaga.

d) Biaya Publikasi/total biaya (R14)

Berdasarkan rasio kinerja tujuan pertama tentang publisitas, BNIS merupakan yang paling konsen terhadap edukasi serta pengenalan produk di berbagai media informasi. Tercatat dari 2011-2014, BNIS memperoleh 6.45\%. Hasil ini sangat mengejutkan, karena BNIS termasuk bank syariah yang tergolong baru berdiri sejak 2010. Dengan demikian, sudah sepatutnya bank syariah lain agar bisa mencontoh apa yang dilakukan oleh BNIS dengan lebih meningkatkan edukasi melalui publikasi keunggulan-keunggulan yang dimiliki oleh bank syariah, agar kedepan produk-produk yang ditawarkan mudah dikenal oleh masyarakat. Selain itu, dengan adanya porsi biaya yang dikeluarkan oleh bank syariah untuk publikasi diharapkan agar dapat memberikan edukasi serta mengajak masyarakat agar lebih mengetahui dan lebih menerima bank syariah. Setidaknya, dengan upaya edukasi yang dilakukan bank syariah akan bisa menyadarkan masyarakat untuk beralih ke bank syariah serta meninggalkan ribawi yang terdapat didalam sistem perbankan konvensional.

\section{Rasio Kinerja Maqashid Indeks Kedua (Justice/Al-'AdI)}

Pada maqashid indeks yang kedua, penulis hanya menggunakan satu rasio dari tiga rasio, yaitu rasio mudharabah dan musyarakah. Dari hasil pengamatan selama tahun 2011-2014, BIMB hanya mengalokasikan dana mudharabah dan musyarakah pada tahun 2011 dan CIMBiB hanya mengalokasikan di tahun 2014. Adapun hasil perhitungan bisa dilihat pada tabel dibawah ini.

\section{a) Mudharabah dan Musyarakah/Total Pembiayaan (R22)}

Kinerja maqashid indeks tujuan kedua, yaitu rasio mudharabah dan musyarakah. Hasil menunjukkan bahwa perbankan syariah di Indoensia dan Malaysia megalami perkembangan yang fluktuatif selama tahun 2011-2014. Praktis, ini dialami oleh bank syariah baik yang ada di Indonesia dan Malaysia. Selanjutnya, Bank syariah dengan kinerja terbaik selama tahun penelitian adalah BMI dengan nilai 47.79\%. Sementara itu, berdasarkan pengamatan selama tahun tersebut bank syariah yang paling rendah kinerjanya adalah BIMB dengan 0.01\%. Selanjutnya, banyak di antara bank syariah di Malaysia tidak menggunakan akad mudharabah untuk pembiayaan mereka. Hal ini terjadi karena akad mudharabah digunakan pada industri keuangan syariah di Malaysia ini berada pada pos-pos penempatan dana (investasi) yang termasuk kedalam investasi sektor keuangan. Sedangkan, rasio pembiayaan mudharabah dan musyarakah merupakan representasi dari bagi hasil yang dilakukan bank terhadap sektor riil dan bukan pada sektor keuangan. Namun, dengan hasil tersebut BMI dinilai lebih baik dalam 
upaya meningkatkan produk berbasis risk sharing (equity based) dari pada produk berbasis hutang saja (debt based). Selain itu, adanya produk mudharabah dan musyarakah ini maka bank syariah telah meninggalkan sistem bunga (riba), karena produk-produk ini menggunakan sistem bagi hasil (Profit and Loss Sharing) yang sesuai dengan tujuan adanya bank syariah. Selain itu, rasio ini juga menilai seberapa besar bank syariah memberikan manfaat untuk kesejahteraan melalui sistem bagi hasil dari akad dan produk yang terdapat pada bank syariah.

\section{Rasio Kinerja Maqashid Indeks Ketiga (Welfare/Al-Maslahah)}

a) Net Income/Total aset (R3')

Pada rasio kinerja maqashid indeks tujuan ketiga, bank syariah yang konsisten dan mempunyai nilai rasio profitabilitas tertinggi adalah BIMB dengan 3.36\% dan terendah adalah BRIS dengan $0.40 \%$. Dalam keterkaitannya dengan maqashid indeks yang ketiga (maslahah), BIMB dapat dikatakan memiliki kontribusi maslahah yang lebih baik dibandingkan dengan bank syariah lainnya. Adanya laba besar yang dihasilkan oleh bank syariah maka akan berdampak positif bagi bank tersebut. Selain itu, dapat juga memberi kemaslahatan kepada nasabah, pemilik modal (investor) dan masyarakat yang didapat dilihat melalui zakat perusahaan yang kemudian memberikan kontribusi pada mustahik. Bahkan, dengan laba besar yang dihasilkan maka nasabah dan pemilik modal (investor) masing-masing mendapatkan tambahan bagi hasil dan pemilik modal tidak mengkhawatirkan dana yang diinvestasikan pada bank syariah. Hal ini juga sejalan dengan koridor maqashid syariah yang menunjukkan bahwa bank syariah telah ikut serta dalam upaya melakukan penjagaan terhadap harta (hifzhul maal).

b) Dana Zakat/Net Aset (R32)

Berdasarka hasil perhitungan untuk alokasi dana zakat yang disalurkan industri perbankan syariah menunjukkan bahwa BIMB merupakan bank syariah yang memiliki kontribusi yang lebih baik selama tahun 2011-2014 dengan nilai 0.30\%. hasil tersebut juga diperkuat oleh data kualitatif di laporan tahunan bank yang bersangkutan. Berdasarkan data laporan tahunan BIMB tahun 2014 disebutkan, bahwa dana zakat yang diperoleh didistribusikan kepada masyarakat melalui kegiatan-kegiatan sosial, seperti pemberian beasiswa pendidikan, pemberian kesehatan gratis, pembangunan sekolah di daerah terpencil, pemberian renovasi rumah gratis bagi masyarakat lingkungan yang kurang mampu, perbaikan kondisi hutan dan pantai sekitar yang rusak untuk menghijaukan kembali dan masih banyak lagi kegiatan sosial lainnya (Laporan Tahunan BIMB, 2014). Dalam koridor maqashid syariah, dana zakat yang diberikan dari bank syariah kepada masyarakat adalah upaya bank syariah dalam menjaga terhadap lima aspek dari maqashid syariah melalui program pemberdayaan zakat.

c) Investasi di Sektor Riil (R33)

Hasil perhitungan investasi sektor riil perbankan syariah menunjukkan bahwa, BSM dan merupakan bank syariah yang paling konsisten kinerjanya selama tahun 2011 2014 dengan nilai mencapai 84-89\%. Dengan demikian, dapat disimpulkan bahwa investasi yang dilakukan oleh kedua bank tersebut hampir seluruhnya menyentuh sektor riil dan sangat sedikit dana yang disalurkan untuk sektor keuangan. Namun, jika dilihat dari konsistensi BSM lebih unggul jika dibandingkan dengan yang lain. Kondisi tersebut dibuktikan dari besaranya dana investasi yang disalurkan oleh BSM di sektor riil. Bahkan 
pencapaian di tahun 2013 merupakan yang tertinggi selama tahun 2011-2014. Selanjutnya, berdasarkan data yang diperoleh dari laporan tahunan BSM dari tahun 2011-2013, seluruh total dana investasi yang disalurkan ke pembiayaan mencapai 24.50\%. Dana tersebut disalurkan oleh BSM ke beberapa sektor, seperti korporasi, komersial (menengah), consumer dan usaha mikro dan kecil. Dari seluruh dana yang disalurkan ke empat sektor tersebut, 30.30\% atau sebesar Rp 7,034,194.00 juta disalurkan ke sektor usaha mikro dan kecil. Ini menjunjukkan bahwa BSM merupakan bank syariah yang konsen dalam upaya mendorong pertumbuhan ekonomi di sektor riil. Secara khusus, investasi tersebut disalurkan melalui pembiayaan yang ke beberapa instansi pemerintah. Diantaranya adalah melalui Kementerian Koperasi, Kementerian Kelautan dan Perikanan, Kementerian Pertanian dan Kementerian Lingkungan Hidup (Laporan Tahunan BSM, 2013).

Kondisi diatas mengindikasikan bahwa, keberadaan investasi pada sektor riil akan sangat berpengaruh terhadap adanya atau tidak peran perbankan syariah di sana. Karena, tujuan adanya perbankan syariah adalah menciptakan kemaslahatan bukan saja pada shareholder perbankan, melainkan memberi manfaat bagi masyarakat secara luas. Sehingga, bank syariah sebagai lembaga intermediasi juga bertanggungjawab atas kewajibannya untuk meningkatkan kualitas hidup sosial-ekonomi masyarkat. Hal ini baru bisa dikatakan bahwa bank syariah sejalan dengan tujuannya, yaitu menciptakan sistem keuangan Islam yang kompetitif, efisien dan memenuhi prinsip syariah dengan mampu mendukung perekonomian sektor riil secara langsung melalui kegiatan berbasis bagi hasil (plofit and loss sharing).

\section{Kinerja Perbankan Syariah Indonesia dan Malaysia Sesuai Indikator Performance Indeks}

Langkah kedua penelitian ini adalah mengakumulasi langkah pertama (nilai rasio) secara keseluruhan. Selanjutnya, penulis akan menguraikan kienrja bank syariah berdasarkan Performance Indeks (PI) dari tahun 2011 sampai dengan 2014. Berikut di bawah ini hasil perhitungan PI yang mencakup tiga kategori; pendidikan (education), keadilan (justice) dan kesejahteraan (maslahah).

Tabel. 5.4 Perhitungan Berdasarkan Indikator Kinerja 2011-2014

\begin{tabular}{|c|c|c|c|c|c|c|c|c|c|c|}
\hline \multirow{2}{*}{$\begin{array}{c}\mathrm{Na} \\
\mathrm{ma} \\
\mathrm{Ban} \\
\mathbf{k}\end{array}$} & \multirow{2}{*}{$\mathbf{R 1}^{1}$} & \multirow{2}{*}{$\mathbf{R 1}^{2}$} & \multirow{2}{*}{$\mathbf{R 1}^{3}$} & \multirow{2}{*}{$\mathbf{R 1}^{4}$} & $\begin{array}{l}\mathrm{PI}< \\
01>\end{array}$ & $\begin{array}{l}\mathrm{PI}< \\
02>\end{array}$ & \multirow{2}{*}{ R3 $^{1}$} & \multirow{2}{*}{$\mathrm{R}^{2}$} & \multirow{2}{*}{$\mathrm{R}^{3}{ }^{3}$} & $\begin{array}{l}\mathrm{PI}< \\
03>\end{array}$ \\
\hline & & & & & Total & $\mathbf{R}^{2}$ & & & & Total \\
\hline BMI & $\begin{array}{c}0.001 \\
199\end{array}$ & $\begin{array}{c}0.000 \\
344\end{array}$ & $\begin{array}{c}0.001 \\
312\end{array}$ & $\begin{array}{c}0.003 \\
139\end{array}$ & $\begin{array}{c}0.005 \\
994\end{array}$ & $\begin{array}{c}0.062 \\
941\end{array}$ & $\begin{array}{c}0.000 \\
581\end{array}$ & $\begin{array}{c}0.000 \\
043\end{array}$ & $\begin{array}{c}0.081 \\
616\end{array}$ & $\begin{array}{c}0.082 \\
240\end{array}$ \\
\hline BSM & $\begin{array}{c}0.000 \\
448\end{array}$ & $\begin{array}{c}0.000 \\
103\end{array}$ & $\begin{array}{c}0.001 \\
901\end{array}$ & $\begin{array}{c}0.003 \\
217\end{array}$ & $\begin{array}{c}0.005 \\
669\end{array}$ & $\begin{array}{c}0.018 \\
073\end{array}$ & $\begin{array}{c}0.000 \\
814\end{array}$ & $\begin{array}{c}0.000 \\
062\end{array}$ & $\begin{array}{c}0.096 \\
162\end{array}$ & $\begin{array}{c}0.097 \\
037\end{array}$ \\
\hline $\begin{array}{c}\text { BRI } \\
\text { S }\end{array}$ & $\begin{array}{c}0.000 \\
000\end{array}$ & $\begin{array}{c}0.000 \\
000\end{array}$ & $\begin{array}{c}0.002 \\
355\end{array}$ & $\begin{array}{c}0.002 \\
827\end{array}$ & $\begin{array}{c}0.005 \\
182\end{array}$ & $\begin{array}{c}0.033 \\
622\end{array}$ & $\begin{array}{c}0.000 \\
349\end{array}$ & $\begin{array}{c}0.000 \\
034\end{array}$ & $\begin{array}{c}0.085 \\
726\end{array}$ & $\begin{array}{c}0.086 \\
108\end{array}$ \\
\hline $\begin{array}{c}\text { BNI } \\
\text { S }\end{array}$ & $\begin{array}{c}0.000 \\
336\end{array}$ & $\begin{array}{c}0.000 \\
000\end{array}$ & $\begin{array}{c}0.001 \\
540\end{array}$ & $\begin{array}{c}0.005 \\
353\end{array}$ & $\begin{array}{c}0.007 \\
230\end{array}$ & $\begin{array}{c}0.017 \\
923\end{array}$ & $\begin{array}{c}0.000 \\
734\end{array}$ & $\begin{array}{c}0.000 \\
057\end{array}$ & $\begin{array}{c}0.078 \\
783\end{array}$ & $\begin{array}{c}0.079 \\
574\end{array}$ \\
\hline MIB & $\begin{array}{c}0.000 \\
221\end{array}$ & $\begin{array}{c}0.000 \\
000\end{array}$ & $\begin{array}{c}0.002 \\
030\end{array}$ & $\begin{array}{c}0.000 \\
872\end{array}$ & $\begin{array}{c}0.003 \\
123\end{array}$ & $\begin{array}{c}0.000 \\
018\end{array}$ & $\begin{array}{c}0.002 \\
923\end{array}$ & $\begin{array}{c}0.000 \\
288\end{array}$ & $\begin{array}{c}0.090 \\
991\end{array}$ & $\begin{array}{c}0.094 \\
202\end{array}$ \\
\hline $\begin{array}{c}\text { BIM } \\
\text { B }\end{array}$ & $\begin{array}{c}0.000 \\
012\end{array}$ & $\begin{array}{c}0.001 \\
157\end{array}$ & $\begin{array}{c}0.000 \\
399\end{array}$ & $\begin{array}{c}0.000 \\
566\end{array}$ & $\begin{array}{c}0.002 \\
135\end{array}$ & $\begin{array}{c}0.008 \\
988\end{array}$ & $\begin{array}{c}0.001 \\
476\end{array}$ & $\begin{array}{c}0.000 \\
254\end{array}$ & $\begin{array}{c}0.072 \\
120\end{array}$ & $\begin{array}{c}0.073 \\
850\end{array}$ \\
\hline $\begin{array}{c}\text { CIM } \\
\text { B }\end{array}$ & $\begin{array}{c}0.000 \\
170\end{array}$ & $\begin{array}{c}0.000 \\
375\end{array}$ & $\begin{array}{c}0.000 \\
209\end{array}$ & $\begin{array}{c}0.000 \\
324\end{array}$ & $\begin{array}{c}0.001 \\
078\end{array}$ & $\begin{array}{c}0.000 \\
650\end{array}$ & $\begin{array}{c}0.001 \\
698\end{array}$ & $\begin{array}{c}0.000 \\
073\end{array}$ & $\begin{array}{c}0.066 \\
736\end{array}$ & $\begin{array}{c}0.068 \\
506\end{array}$ \\
\hline
\end{tabular}


Jurnal Ekonomi dan Perbankan Syariah

Vol. 3. No.2, 0ctober 2015: 47-66, ISSN (cet): 2355-1755

\begin{tabular}{|c|c|c|c|c|c|c|c|c|c|c|} 
RHB & 0.000 & 0.000 & 0.000 & 0.001 & 0.001 & 0.027 & 0.001 & 0.000 & 0.072 & 0.074 \\
$\mathrm{iB}$ & 004 & 000 & 452 & 493 & 949 & 750 & 344 & 045 & 641 & 030 \\
\hline
\end{tabular}

Sumber: data diolah

\section{a) Maqashid Indeks Pertama (Education Individual)}

Berdasarkan data tabel di atas, BNIS memiliki capaian kinerja terbaik dari tahun 2011-2014. Hal ini diperkuat oleh hasil PI (01) dengan nilai 0.72\%. Dibawahnya diikuti oleh BMI dan BSM, masing-masing memperoleh nilai $0.60 \%$ dan $0.57 \%$. Dan terendah adalah CIMB Islamic dengan 0.19\%. Dengan hasil tersebut, BNI dinilai lebih baik kontribusi di bidang pendidikan dibandingkan dengan bank syariah lain. Bahkan, dengan predikat bank syariah yang baru berdiri di tahun 2010 pun tidak menghalangi BNIS meraih berbagai prestasi di bidang lain (Laporan Tahunan BNIS, 2014).

\section{b) Maqashid Indeks Kedua (Justice)}

Berdasarkan keterangan gambar di atas, selama tahun 2011-2014 BMI merupakan bank syariah yang paling konsen terhadap rasio mudharabah dan musyarakah dengan nilai 6.29\%. Selain itu, capaian-capaian ini juga didasari oleh kegiatan dan pencitraan BMI sebagai bank syariah pertama di Indonesia. Dengan hasil tersebut, ini juga menunjukkan bahwa kinerja BMI untuk meningkatkan kesejahteraan (kemaslahatan) masyarkat melalui sektor riil sangat besar. Hal ini juga sejalan dengan tujuan dari investasi dalam Islam, yaitu menjamin distribusi kekayaan yang adil serta mencipatakan produktivitas di sektor riil itu sendiri.

Selain BMI, BRIS dan RHBiB merupakan dua bank syariah yang kinerjanya meningkat dari tahun 2011-2014 dengan nilai 3.36\% dan 2.77\%. Selama tahun tersebut, dua bank syariah yang bersangkutan terus mengalami tren kenaikan di setiap tahun. Dengan demikian, dapat dikatakan bahwa kedua bank syariah tersebut memiliki potensi besar dalam meningkatkan kesejahteraan (kemaslahatan) masyarakat melalui produkproduk yang inovatif sesuai dengan prinsip bagi hasil (profit and loss sharing). Sementara itu, kondisi diatas berbanding terbalik dengan BIMB dan CIMBiB. Hal ini terjadi karena, BIMB dan CIMBiB hanya mengalokasikan dana mudharabah dan musyarakah di tahun 2013 dan 2014. Hal ini tentu sebelumnya sudah dijelaskan, bahwa ini lumrah terjadi dikarenakan banyak di antara bank syariah di Malaysia tidak lagi menggunakan akad mudharabah untuk pembiayaan mereka, melainkan akad mudharabah pada industri perbankan syariah di Malaysia ini berada pada pos-pos penempatan dana (investasi) yang termasuk ke dalam investasi sektor keuangan atau bukan termasuk penyaluran dana di sektor riil.

Namun, yang perlu menjadi perhatian adalah bahwa hampir seluruh pembiayaan yang sifatnya konsumtif justru paling banyak diminati dan memiliki porsi besar baik di Indonesia dan Malaysia. Hal ini tentu evaluasi besar bagi bank syariah agar sistem bagi hasil (Profit and Loss Sharing) berupa mudharabah dan musyarakah ini semestinya menjadi produk unggulan yang harus diperjuangkan oleh bank syariah. Selain itu, upaya BI dan BNM sekaligus lembaga yang memilki wewenang semestinya mengatur alokasi dana untuk pembiayaan di bank syariah dengan seimbang, agar hadirnya bank syariah bukan saja mengejar market share dan profit yang tinggi. Melainkan agar tetap sejalan dengan Islamic Worldview (rujukan Islam) dan tujuan adanya bank syariah itu sendiri. 
64 | AL-Ghifari, Handoko \& Yani: Analisis Kinerja Perbankan Syariah Di Indonesia Dan Malaysia.........

\section{c) Maqashid Indeks Ketiga (Maslahah)}

Berdasarkan keterangan gambar di atas, nilai keseluruhan BSM merupakan yang tertiggi selama tahun 2011-2014 dengan perolehan sebesar 9.70\%. Sementara itu, nilai terendah adalah CIMB Islamic dengan hanya 6.85\%. Dengan demikian, dari pengamatan di atas penulis dapat mengambil kesimpulan bahwa BSM adalah bank syariah yang memiliki kontribusi lebih baik dalam meningkatakan kesejahteraan seluruh stakeholder perbankan syariah dari sisi maslahah.

\section{Kinerja Perbankan Syariah di Indonesia dan Malaysia Berdasarkan Maqashid Indeks}

Langkah terakhir dalam penelitian ini adalah mengakumulasi langkah pertama (nilai rasio) dan kedua (Performance Indeks). Selanjutnya, akan diuraikan kienrja bank syariah di Indonesia dan Malaysia dari total keseuruhan berdasarkan maqashid indeks selama tahun 2011 sampai dengan 2014.

Tabel. 5.5 Kinerja Perbankan Syariah di Indonesia dan Malaysia Berdasarkan Maqashid Indeks Tahun 2011-2014

\begin{tabular}{|l|l|l|l|l|l|}
\hline Nama Bank & $\begin{array}{l}\text { PI }<\mathbf{0 1} \\
\boldsymbol{>}\end{array}$ & $\begin{array}{l}\text { PI }<\mathbf{0 2} \\
\boldsymbol{>}\end{array}$ & $\begin{array}{l}\text { PI }<\mathbf{0 3} \\
\boldsymbol{>}\end{array}$ & Total & Rangking \\
\hline Bank Muamalat Indonesia & $0.60 \%$ & $6.29 \%$ & $8.22 \%$ & $15.12 \%$ & 1 \\
\hline Bank Mandiri Syariah & $0.57 \%$ & $1.81 \%$ & $9.70 \%$ & $12.08 \%$ & 3 \\
\hline Bank Rakyat Indonesia Syariah & $0.52 \%$ & $3.36 \%$ & $8.61 \%$ & $12.49 \%$ & 2 \\
\hline Bank Negara Indonesia Syariah & $0.72 \%$ & $1.79 \%$ & $7.96 \%$ & $10.47 \%$ & 4 \\
\hline Maybank Islamic Berhad & $0.31 \%$ & $0.002 \%$ & $9.42 \%$ & $9.73 \%$ & 6 \\
\hline Bank Islam Malaysia Berhad & $0.21 \%$ & $0.90 \%$ & $7.38 \%$ & $8.50 \%$ & 7 \\
\hline CIMB Islamic Bank Berhad & $0.11 \%$ & $0.07 \%$ & $6.85 \%$ & $7.02 \%$ & 8 \\
\hline RHB Islamic Bank & $0.19 \%$ & $2.77 \%$ & $7.40 \%$ & $10.37 \%$ & 5 \\
\hline
\end{tabular}

Sumber: data diolah

Berdasarkan gambar diatas dapat dikatakan bahwa, BMI adalah bank syariah yang paling konsen dengan maqashid indeks. Hal ini memastikan bahwa, bank tersebut memiliki tingkat kinerja terbaik selama tahun pengamatan 2011-2014 dengan nilai $15.12 \%$. Kemudian, bank syariah yang juga berpeluang untuk terus meningkatkan kinerjanya adalah BRIS, BSM, BNIS dan RHBiB. Hal ini terbukti bahwa keempat bank syariah tersebut mencapai nilai 10\%. Sementara itu, BIMB, MIB dan CIMBiB hanya memperoleh nilai maqashid indeks dibawah 10\%. Sehingga, ketiga bank syariah tersebut perlu memperhatikan kembali kinerja berdasarkan maqashid indeks di tahun mendatang. Secara praktis, yang pencapaiannya terburuk adalah CIMBiB dengan perolehan $7.02 \%$.

Dengan demikian, hasil penelitian ini menunjukkan bahwa kinerja industri perbankan syariah di Indonesia lebih baik dibandingkan dengan kinerja perbankan syariah di Malaysia. Selain itu, hasil ini juga sejalan dengan peneltian yang dilakukan oleh Hilman dan Taufik (2012) dan Luqman dkk (2013), bahwa BMI menjadi bank syariah yang memiliki kinerja terbaik dengan capian rasio tertinggi. Sehingga, dengan begitu dapat dikatakan bahwa BMI menjadi bank syariah yang paling konsen kinerjanya berdasarkan maqashid indeks selama tahun 2008 sampai dengan 2014. 


\section{SIMPULAN}

Tujuan dari penelitian ini adalah untuk mengetahui kinerja perbankan syariah di Indonesia dan Malaysia dan merangking bank syariah berdasarkan Maqashid Indeks yang dikembangkan oleh Mohammed dkk. Untuk mengetahui kinerja perbankan syariah di kedua negara, penulis melakukan perhitungan terhadap 4 bank syariah dari masingmasing negara berdasarkan aset terbesar selama tahun 2011-2014. Empat bank syariah baik di Indonesia terdiri dari BSM, BMI, BRIS dan BNIS. Sementara itu, empat dari Malaysia adalah CIMBiB, BIMB, MIB dan RHBiB. Berdasarkan hasil perhitungan kinerja perbankan syariah berdasarkan Maqashid Indeks di Indonesia secara keseluruhan di tahun 2011-2014. Hasil menunjukkan bahwa BMI memilki kinerja terbaik dengan capaian nilai sebesar $15.12 \%$ dan kinerja terendah 7.02\% diperoleh CIMBiB. Selanjutnya, dibawahnya secara berutan BRIS, BSM, RHBiB, MIB dan BIMB dengan nilai $12.49 \%$, $12.08 \%, 10.47 \%, 10.37 \%, 9.73 \%, 8.50 \%$ dan 7.02\%. Dengan demikian, kinerja perbankan syariah di Indonesia lebih baik dibandingkan dengan perbankan syariah di Malaysia.

\section{DAFTAR PUSTAKA}

Badan Pusat Statistik. (2014). Statistik Indonesia (Statistical Yearbook of Indonesia). Jakarta: BPS.

Badreldin, A. M. (2009). Measuring the Performance of Islamic Bank by Adapting Conventional Ratios. 1-28.

Bank Indonesia. (2012, 2013, 2014). Annual Report. Retrieved November 11, 2014, from www.bi.go.id.

Bank Islam Malaysia Berhad. (2011, 2012, 2013, 2014). Annual Report. Retrieved November 23, 2014, from www.bankislam.com.my.

Bank Muamalat Indonesia. (2011, 2012, 2013, 2014). Annual Report. Retrieved November 21, 2014, from www.muamalatbank.com.

Bank Negara Indonesia Syariah. (2011, 2012, 2013, 2014). Annual Report. Retrieved November 21, 2014, from www.bnisyariah.co.id.

Bank Negara Malaysia. (2012, 2013, 2014). Annual Report. Retrieved November 11, 2014, from http://www.bnm.gov.my/.

Bank Rakyat Indonesia Syariah. (2011, 2012, 2013, 2014). Annual Report. Retrieved November 21, 2014, from www.bnisyariah.co.id.

Bank Syariah Mandiri. (2011, 2012, 2013, 2014). Annual Report. Retrieved November 21, 2014, from www.syariahmandiri.co.id.

Bedoui, M. H. (Januari 2012). Shari'a-based ethical performance measurement framework. 1-12.

Chapra, M. U. (2000). Sistem Moneter Islam. Jakarta: Gema Insasi Press \& Tazkia Press.

CIMB Islamic Bank Berhad. (2011, 2012, 2013, 2014). Annual Report. Retrieved November 23, 2014, from www.cimbislamic.com.

Ernest, \& Young. (2013-2014). World Islamic Banking Competitivness Report. The Transition Begin, 1-84.

Fazlulrrahman. (1984). Islam. Bandung: Penerbit Pustaka.

Ginanjar, R. D. (2013). Pengaruh Non Performing Financing terhadap Profitabilitas Bank Syariah (Studi pada Perbankan Syariah yang terdaftar di Bursa Efek Indonesia.

Hameed, S., Pramono, S. d., Nazli, M., \& dkk. (2004 ). Alternative Disclosure and Performance Measures for Islamic Banks. Working Paper: IIUM, 1-37.

Hawary, D. E., Grais, W., \& Iqbal, Z. (2004). Regulating Islamic financial institutions: The nature of the regulated. World Bank Policy Research Working Paper, 1-49.

Iqbal, Z. (1997, Juni). Islamic Financial System. Finance \& Development, 42-45. 
66 | AL-Ghifari, Handoko \& Yani: Analisis Kinerja Perbankan Syariah Di Indonesia Dan Malaysia.........

(2013). Islamic Finance Industry Outperfomrs. Malaysia's Islamic Finance Centre.

Ismail, N. (2011). Maqashid Syariah Dalam Ekonomi Islam. Jakarta: Gema Insani Press.

Kuppusamy, M. d. (2010). Measurement of Islamic Banks Performance Using a Shariah Conformity Measurement of Islamic Banks Performance Using a Shariah Conformity and Profitablity Model . Jurnal Review of Islamic Economics, 13 , 35-48.

Luqman, Jazil, T., \& dkk. (2013). The Performance Selected Malaysian and Indonesian Islamic Bank based on the Maqashid Al-Shari'ah Approach. Unpublished, 1-24.

Malaysia International Islamic Finance Centre. (2013). Islamic Finance Industry Outperforms In 2013. Kuala Lumpur: INCEIF.

Maybank Islamic Berhad. (2011, 2012, 2013, 2014). Annual Report. Retrieved November 23, 2014, from www.maybankislamic.com.my.

Mohammed, M. O., \& Taib. (2009). Testing the Performance Measures Based on Maqasid al-Shari'ah (PMMS) 24 Model Selected Islamic and Conventional Banks. 1-15.

Mohammed, M. O., Razak, D. A., \& Taib, F. M. (2008). The Performance Measures of Islamic Banking Based on the Maqasid Framework. Paper of IIUM International Accounting Conference (INTAC IV) held at Putra Jaya Marroitt, 1-17.

Purwanda, E., \& Muttaqien, Z. (2012). Model Pengembangan SDM Industri Perbankan Syariah di indoenesia. Forum Riset Perbankan Syariah $V$, 1-29.

RHB Islamic Bank Berhad. (2011, 2012, 2013, 2014). Annual Report. Retrieved November 23, 2014, from www.rhbislamicbank.com.my.

Shaukat, M. (2008). The Recent Financial Growth of Islamic Banks and Their Fulfilment of Maqasid al-Shariah Gap Analysis. Working jurnal INCEIF Malasyia.

Taufik, M., \& Nugraha, H. F. (2012). Model Penilaian Tingkat Kesehatan Perbankan Syariah: Implementasi Maqashid Indeks di Indonesia dan Yordania. Paper Forum Riset Perbankan Syariah, 1-32.

Yuliani, S. (2012). Analisis Kinerja Keuangan Terhadap Kinerja Sosial Bank Umum Syariah di Indonesia. 1-97.

Zahrah, M. A. (2011). Ushul Fiqih. (S. Ma'shum, Trans.) Jakarta: Pustaka Firdaus.

Zaman, R. M., \& Movassaghi, H. (2002). Interest-Free Islamic Banking: Ideals and Reality. International Journal of Finance, 2428-2442. 